\title{
Meta
}

Journal des traducteurs

Translators' Journal

Vandaele, J. (dir.) (1999) : Translation and the (Re)Location of Meaning. Selected Papers of the CETRA Research Seminars in Translation Studies 1994-1996. CETRA Publications $\mathrm{n}^{\circ} 4$, The Leuven Research Centre for Translation, Communication and Cultures, University of Leuven, Leuven, 449 p.

\section{Sylvie Vandaele}

Volume 48, numéro 4, décembre 2003

URI : https://id.erudit.org/iderudit/008731ar

DOI : https://doi.org/10.7202/008731ar

Aller au sommaire du numéro

Éditeur(s)

Les Presses de l'Université de Montréal

ISSN

0026-0452 (imprimé)

1492-1421 (numérique)

Découvrir la revue

Citer ce compte rendu

Vandaele, S. (2003). Compte rendu de [Vandaele, J. (dir.) (1999) : Translation and the (Re)Location of Meaning. Selected Papers of the CETRA Research Seminars in Translation Studies 1994-1996. CETRA Publications $n^{0} 4$, The Leuven Research Centre for Translation, Communication and Cultures, University of Leuven, Leuven, 449 p.] Meta, 48(4), 591-593.

https://doi.org/10.7202/008731ar d'utilisation que vous pouvez consulter en ligne. 


\section{VAndaele, J. (dir.) (1999): Translation and the (Re)Location of Meaning. Selected Papers of the CETRA Research Seminars in Translation Studies 1994-1996. CETRA Publications $\mathrm{n}^{\circ}$ 4, The Leuven Research Centre for Translation, Communication and Cultures, University of Leuven, Leuven, 449 p.}

Appuyant une vision de la traduction comme le lieu de l'interdisciplinarité par excellence et refusant d'emblée une forme d'élitisme académique qui exclurait certains sujets, Jeroen Vandaele a dirigé un recueil d'articles émanant des séminaires du CETRA entre 1994 et 1996 et traitant de thèmes variés: journalisme, documentaires, films, sociolectes, littérature enfantine, etc., conjointement avec des thématiques généralement perçues comme plus prestigieuses telles que politique, normes et littérature, cognition, linguistique et pragmatique. Il regroupe l'ensemble des travaux autour de la question de la «(re)contextualisation du sens", soulignant le caractère indispensable de recherches axées sur les différences culturelles dont la traduction porte les signes explicites. C'est donc l'acte interprétatif sous-jacent à la pratique traductionnelle qui est mis sous examen, Jeroen Vandaele allant jusqu'à affirmer que se demander s'il est légitime de penser la traduction comme une activité de création d'identité culturelle revient, ni plus ni moins, à poser la question de la légitimation de la traductologie elle-même. L'ensemble des articles présentés dans le recueil offrent des pistes de réponses, un certain nombre de travaux se référant à l'approche fonctionnelle et descriptiviste prônée par Toury, mais d'autres s'en écartant de manière substantielle. La question de la (re)contextualisation du sens, qui s'inscrit ici dans le cadre de la problématique des dynamiques culturelles (autrement dit des Cultural Studies) est évidemment liée aux contraintes exercées dans le cadre de l'activité traduisante: par conséquent, cela revient à savoir comment les étudier et comment elles influent sur les choix traductionnels.

Brownlie cherche à élaborer une méthode d'étude de la norme, après avoir fait un bilan de la manière dont cette notion est abordée en traductologie. Il évoque notamment la tension existant entre la norme issue des régularités et celle qui est issue des conventions, c'est-à-dire entre le normal et le normatif. À la lumière de la théorie des polysystèmes, Rudvin fait état des conséquences politiques découlant de la recontextualisation de la littérature populaire dans un nouveau sociolecte, en l'occurrence la transcription de contes et de légendes norvégiennes. Vuorinen présente un projet de recherche visant à examiner la traduction des nouvelles internationales et à évaluer les transformations culturelles qui y sont liées. Pegenaute aborde la question des contraintes idéologiques imposées aux traductions littéraires sous la dictature de Franco et évoque l'importance d'une censure qui cherche à identifier - et à éradiquer - les influences menaçantes provenant de l'étranger. Kurth souligne le contraste entre l'abondance des travaux menés sur la métaphore et leur rareté en traductologie. Il explore l'équivalence partielle des métaphores traduites en littérature, en faisant appel à un double cadre théorique, pragmatique et cognitif, notamment au modèle des scenes-and-frames de Fillmore. S'intéressant aux contraintes imposées aux traductions dans une revue littéraire nazie, Sturge examine ce qui n'est pas «importé» dans les traductions en Allemagne dans la période où Hitler est au pouvoir, c'est-à-dire dans un contexte où tout élément extérieur introduit dans la culture est perçu comme une menace pour son intégrité. S'intégrant dans le courant des études descriptives, Malingret s'intéresse à la réception d'œuvres littéraires traduites de l'espagnol vers le français et cherche à mettre en évidence la transformation du mode d'intégration dans le système d'accueil à vingt ans d'intervalle. Elle souligne notamment la tension entre l'accueil fait à l'autre et la recherche de la sauvegarde de l'identité. Zabalbeascoa soulève la question de l'inventaire des facteurs éventuels de "relocalisation» du sens et de leur priorité. Fervent partisan de laisser au traducteur la possibilité de justifier ses choix, et ayant à l'esprit une visée pédagogique, il propose un ensemble de critères d'évaluation de "priorités» et de "restrictions» à considérer en situation de traduction. Adoptant une perspective fonctionnaliste, Bogucki s'attaque à la 
problématique des conventions culturelles et montre comment de nouveaux effets comiques peuvent résulter de la difficulté à «recontextualiser» adéquatement le sens d'origine. Zauberga évalue la situation des traductions d'œuvres littéraires étrangères au sein du polysystème letton, en rapport avec le développement de la langue lettone et de l'évolution de la culture. Kocijančič Pokorn examine l'influence de l'idéologie politique du traducteur dans les modalités de recontextualisation d'un classique slovène dans la culture américaine. À travers une étude comparative de la macrostructure et de la microstructure, Desmet questionne les stratégies d'adaptation d'un best-seller de la littérature enfantine anglaise utilisées par les traducteurs dans les versions française et hollandaise. Vandaele analyse le doublage cinématographique en espagnol et en français et rend compte de l'hétérogénéité des phénomènes humoristiques rencontrés. Il argue en faveur de la recherche d'une «adéquation au plan cognitif», indissociable de "l'acceptabilité lexicale». Gercken aborde le choix préalable des références culturelles pertinentes au processus de traduction, ainsi que l'analyse des références réellement prises en compte dans le texte traduit. Faisant appel à l'analyse du discours, Franco étudie le sous-titrage en néerlandais d'un documentaire sur le Brésil. Elle voit, dans le sous-titrage, la trace d'un discours « reconstruit», les choix du traducteur étant largement influencés par les intentions du producteur liées à ses propres convictions socioculturelles. À travers le sous-titrage en portugais de différentes variétés d'anglais, Assis Rosa traite des normes et des stratégies mises en jeu dans la traduction des sociolectes et s'inquiète du caractère réducteur des solutions parfois adoptées. Varela explore le rôle de la situation sociolinguistique du galicien en tant que facteur déterminant de la dynamique culturelle et du système traductionnel en Galicie. Díaz Pérez s'intéresse à la traduction des jeux de mots présents dans l'œuvre de Lewis Carroll, en galicien et en espagnol, et réfute l'allégation de leur intraduisibilité. Colina compare différents groupes (étudiants de langue seconde, étudiants débutants et avancés en traduction, traducteurs professionnels) dont elle cherche à évaluer le comportement devant un certain nombre de déficiences traductionnelles. Coppieters se penche sur le processus d'adaptation s'effectuant entre l'œuvre écrite, le scénario et le film lui-même, le second jouant le rôle "d'inter-texte». Elle relève différentes catégories de changements opérés, qu'elle attribue à des raisons pratiques, à des considérations prenant en compte le public-cible ou à des raisons purement cinématographiques. Hee Kirk évoque le rôle prédominant de la traduction dans l'influence exercée par l'Occident sur la culture coréenne. Il analyse, sous l'angle des paramètres de textualité, la version coréenne de Newsweek et montre comment les différences culturelles sont traitées par les traducteurs. Enfin, Ožbot s'intéresse aux problèmes soulevés par la traduction (de l'italien au slovène) d'un ouvrage traitant d'histoire de la littérature, essentiellement dans un but pédagogique.

Bien que réunissant des travaux remontant à maintenant presque dix ans, l'ouvrage mérite d'être lu, premièrement parce que la thématique abordée, celle de la recontextualisation du sens, est la question fondamentale de l'activité traductionnelle et de sa théorisation. Il est particulièrement intéressant, à l'heure où le concept de «localisation» fait fureur et tend à occulter la diversité des pratiques traductionnelles, de se souvenir que le problème de la «recontextualisation» est le problème fondamental de la traduction et que l'on n'a pas attendu, loin s'en faut, les difficultés posées par l'adaptation de produits commerciaux dans différents pays pour se pencher sur le problème délicat de la tension générée par la mise en présence de plusieurs cultures. Deuxièmement, la variété des modalités traductionnelles envisagées et la référence à de nombreux auteurs en traductologie illustrent de façon intéressante l'incessant aller-retour entre pratique et théorie. Enfin, la postface, écrite par Pym, est également source de réflexion. Un tantinet provocateur, Pym relève que les courants de pensée de la traductologie des années 1990 sont marqués essentiellement par la rupture entre la linguistique et la traductologie, la présence de la première étant perçue comme la marque d'une position prescriptiviste à rejeter à tout prix, la seconde se centrant davantage 
autour d'approches relevant davantage des Cultural Studies. Toutefois, mettant en cause l'écart creusé entre la théorie et la pratique, Pym s'interroge sur le rôle de la mondialisation et de l'évolution du marché de la traduction. Ce faisant, il questionne l'adéquation de la formation des traducteurs et argue que les approches descriptives et prescriptives ne sont au fond que les deux facettes d'une même médaille. Rejetant toutefois une allégeance univoque, que ce soit à la linguistique ou aux Cultural Studies, il plaide, pour les années 2000, en faveur de la réunification d'approches prétendument divergentes et de l'ouverture d'esprit, ce qui ne saurait manquer d'enrichir la traductologie bien mieux que le repliement sur elle-même.

Sylvie Vandaele Université de Montréal, Montréal, Canada

Kaufmann, U. and H. Bergenholtz et al. (1998): Encyclopedic Dictionary of Gene Technology, vol. 1, English (with Spanish equivalents), 385 p. vol. 2, Spanish (with English equivalents). Toronto, Lugus Libros, $411 \mathrm{p}$.

Four years is a long time to wait for the review of any dictionary, especially one dealing with a field as new and as rapidly developing as gene technology. One of the banes of specialised lexicography is that dictionaries are often put out by small publishers who have no means of promoting them, with the result that useful work too often goes unnoticed. This seems to be the case of the Encyclopedic Dictionary of Gene Technology, as the present reviewer has no knowledge of any mention being made in the major lexicography journals.

In spite of the delay, it is still worthwhile to present this dictionary since it incorporates several original features, which its authors claim to be important lexicographical innovations. The present English-Spanish dictionary is in fact an adaptation of a previous DanishEnglish dictionary ${ }^{1}$, put out by the principal authors in 1992, and which created quite a sensation at the time in Denmark. The Danish dictionary was presented as a prototype of the way that specialised lexicography should perform according to the precepts laid down by Bergenholtz and Tarp ${ }^{2}$ (one of the co-authors of the English-Spanish version). Part of the polemics concerned the claim that specialised lexicography was user-centred, whereas terminology was subject-centred, and thus less easily accessible. In the Danish dictionary, great pains were taken to define the potential users and their needs, with some unusual though perfectly justified results. One of these was the use of the two languages: since the user was assumed to be a Danish and not an English speaker, encyclopedic information was given exclusively in Danish, though English figured not only in equivalents, but also in many collocations, designed to help Danes who wanted not only to read English-language texts on the subject, but also to write in that language.

This unbalance of languages is not present in the English-Spanish dictionary, or at least not in the same form, but most of the other original features are. One of these features is the basic structure of the dictionary itself. In addition to a preface and a section giving information on how and why the dictionary was made, there is a particularly important "Guide to the Use of the Dictionary" and a comprehensive introduction to molecular biology which precede the alphabetical core, consisting of some 4,500 headwords in both languages, which compares favorably to the 6,000 entries of a monolingual specialist dictionary ${ }^{3}$.

The preface lays out the basic objectives of the dictionary, underlining its interdisciplinary nature (the two main authors are respectively a biologist and a lexicographer). "Background Information" lists targeted user groups and needs to which the dictionary is intended and explains how it came into being and what corpora were drawn on. The sources appear in the form of an exhaustive bibliography. 